\title{
A new species of Peniculus (Copepoda: Siphonostomatoida) parasitizing mesopelagic myctophid fish: first discovery of colonization of the genus in deep water
}

\author{
Susumu Ohtsuka ${ }^{1, *}$, Jun Nishikawa ${ }^{2}$, and Geoffrey A. Boxshall ${ }^{3}$ \\ 1 Takehara Station, Seotuchi Field Science Center, Graduate School of Biosphere Science, Hiroshima University, 5-8-1 Minato-machi, \\ Takehara, Hiroshima 725-0024, Japan \\ 2 Department of Marine Biology, School of Marine Science and Technology, Tokai University, Orido, Shimizu, Shizuoka 424-8610, \\ Japan \\ 3 Life Sciences Department, The Natural History Museum, Cromwell Road, London SW7 5BD, United Kingdom
}

Received 29 August 2018, Accepted 1 November 2018, Published online 26 November 2018

\begin{abstract}
Peniculus hokutoae $\mathrm{n}$. sp. is described on the basis of an ovigerous adult female parasitizing the caudal fin of the myctophid fish Symbolophorus evermanni (Gilbert, 1905), collected from Suruga Bay, Japan. This is the first record of parasitism by this genus on mesopelagic myctophid fish. The new species is easily distinguished from other congeners in: (1) the presence of a conical process anterior to the rostrum; (2) the secondary elongation of the first pedigerous somite; (3) the incorporation of the third and fourth pedigerous somites into the trunk; (4) the unilobate maxillule bearing two unequal apical setae; (5) the lack of any processes on the first segment of the maxilla. Four morphological patterns of the cephalothorax, neck and anterior parts of the trunk can be found in the genus. We infer that initial colonization of a mesopelagic myctophid fish as host is likely to have occurred when the diurnally-migrating myctophid host was feeding in near-surface waters at night and was exposed to infective stages of Peniculus.
\end{abstract}

Key words: colonization, diel vertical migration, mesopelagic, Myctophidae, Peniculus, Pennellidae.

Résumé - Une nouvelle espèce de Peniculus (Copepoda : Siphonostomatoida) parasitant les poissons Myctophidae mésopélagiques : première découverte de la colonisation du genre en eau profonde. Peniculus hokutoae $\mathrm{n}$. sp. est décrit sur la base d'une femelle adulte ovigère parasitant la nageoire caudale du poisson Myctophidae Symbolophorus evermanni (Gilbert, 1905), prélevée à Suruga Bay, au Japon. Il s'agit du premier signalement de parasitisme de ce genre chez les poissons myctophidés mésopélagiques. La nouvelle espèce se distingue facilement des autres congénères par : (1) la présence d'un processus conique antérieur au rostre ; (2) l'élongation secondaire du premier somite pédigère ; (3) l'incorporation des troisième et quatrième somites pédigères dans le tronc ; (4) le maxillule unilobé portant 2 soies apicales inégales ; (5) l'absence de processus sur le premier segment du maxillaire. Quatre types morphologiques du céphalothorax, du cou et des parties antérieures $\mathrm{du}$ tronc peuvent être trouvés dans le genre. Nous en déduisons que la colonisation initiale d'un poisson myctophidé mésopélagique en tant qu'hôte a probablement eu lieu lorsque l'hôte myctophidé, à migration diurne, se nourrissait la nuit dans des eaux proches de la surface et a été exposé aux stades infectants de Peniculus.

\section{Introduction}

The siphonostomatoid family Pennellidae is a group of highly transformed copepods typically infesting fish as their final hosts, as meso- or ectoparasites [4]. The family currently accommodates 24 valid genera [4, 5, 20]. The genera Peniculus von Nordmann, 1832 and Pennella Oken, 1815 tend to parasitize shallow-water fish, while other genera, such as Sarcotretes Jungersen, 1911, Lernaeenicus Lesueur, 1824, Protosarcotretes Ohtsuka, Lindsay \& Izawa, 2018, Cardiodectes Wilson, 1917.

\footnotetext{
*Corresponding author: ohtsuka@hiroshima-u.ac.jp
}

Ophiolernaea Shiino, 1958 and Parina Kazachenko \& Avdeev, 1977 infest deep-sea fish [1-5, 20]. Myctophid fish are one of main host groups for these deep-sea pennellids [3, 20].

During deep-sea zooplankton surveys in Suruga Bay, middle Japan by Tokai University, an undescribed species of the pennellid genus Peniculus infesting the caudal fin of a myctophid fish (Fig. 1A) was found, in addition to the recent discovery of a new pennellid genus and species Protosarcotretes nishikawai Ohtsuka, Lindsay \& Izawa, 2018 [Japanese name: houraieso-no-namida (new), Japanese, meaning a tear drop of Pacific viper fish] parasitic on Pacific viper fish [20]. The present paper provides a taxonomic description of the 

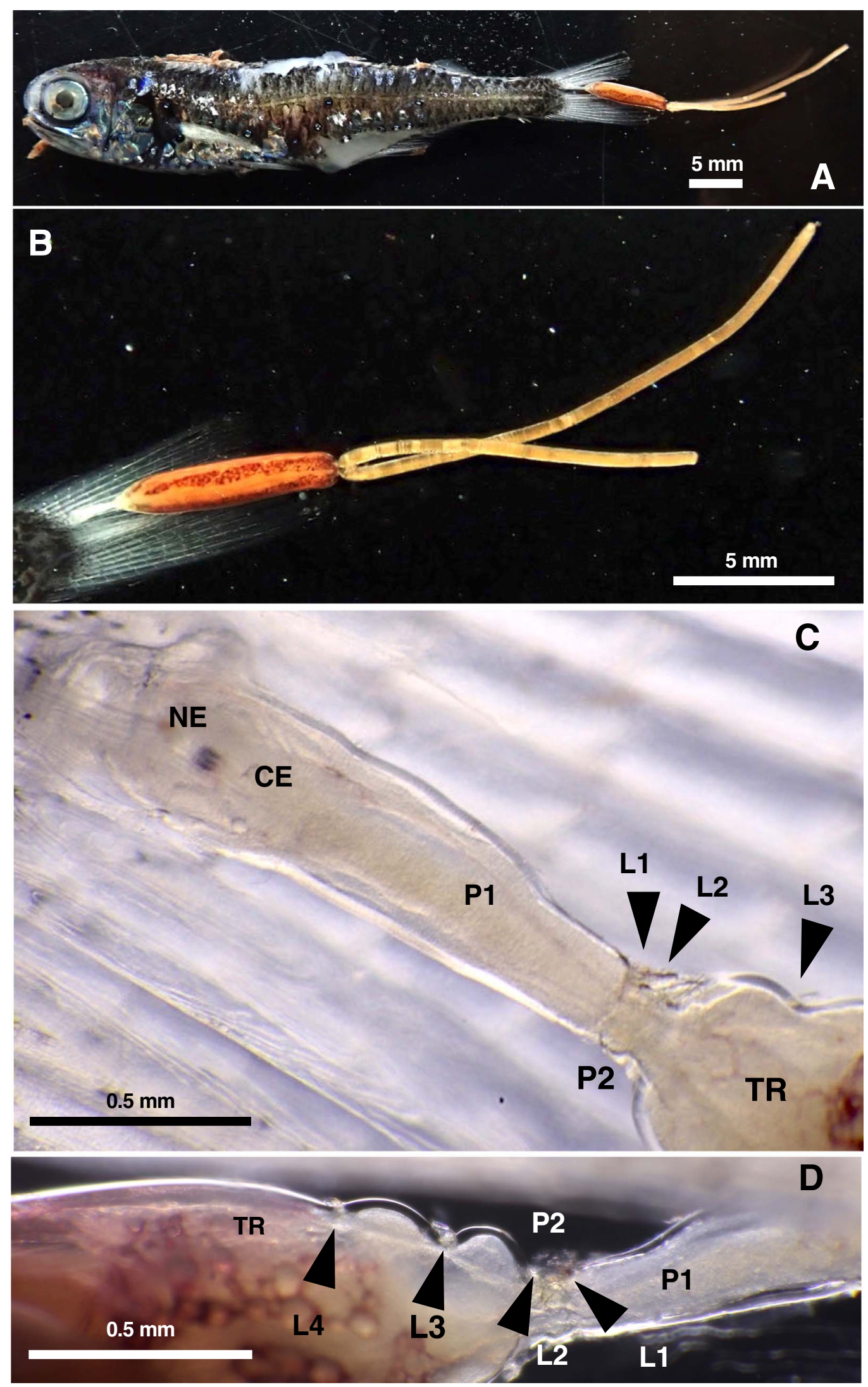

Figure 1. Peniculus hokutoae n. sp., holotype female. (A), (B) Living specimen in-situ on caudal fin of host Symbolophorus evermanni (Gilbert, 1905); (C) Cephalothorax and neck, dorsal view; (D) Neck and anterior part of trunk, lateral view. Abbreviations: CE: dorsal cephalic shield; L1-4: legs 1-4; NE: naupliar eye; P1, 2: pedigerous somites 1 and 2; TR: trunk. 
undescribed new pennellid on the myctophid fish, together with notes on host-specificity, distribution and colonization of Peniculus.

\section{Materials and methods}

A parasitic copepod specimen attached to the caudal fin of its host fish was collected in Suruga Bay $\left(35^{\circ} 03^{\prime} 20^{\prime \prime} \mathrm{N}\right.$, $138^{\circ} 41^{\prime} 00^{\prime \prime} \mathrm{E}$ ), Japan between $11: 26$ and $13: 12$ on July 12, 2018 in an oblique tow (0-917.9 m depth) of the ORI net (335 $\mu \mathrm{m}$ mesh, $1.6 \mathrm{~m}$ mouth diameter) [22] during cruise SRM-18-7-1 of the R/V Hokuto (Tokai University). The copepod specimen was photographed live before being preserved in $99.5 \%$ ethanol (see Figs. 1A and 1B). The only host fish in the plankton sample was identified as Symbolophorus evermanni (Gilbert, 1905) by reference to Nakabo [18]. The copepod was observed in lactophenol using a Humes \& Gooding's [11] slide, and illustrated with the aid of a drawing tube attached to an Olympus microscope. Copepod terminology follows Huys \& Boxshall [12]. The type specimen of the parasitic copepod and the host fish are deposited at the National Museum of Nature and Science, Tsukuba, Japan (NSMT).

\section{Taxonomy}

Order Siphonostomatoida Thorell, 1895

Family Pennellidae Burmeister, 1835

Genus Peniculus von Nordmann, 1832

Remarks. Castro-Romero [7] redefined the diagnosis of the genus Peniculus together with that of other pennellid genera Metapeniculus Castro-Romero \& Baeza-Kuroki, 1985 and Trifur Wilson, 1917. However, some important characteristics were missing from the diagnosis of Peniculus: lack of antennules, for example. Although Boxshall \& Halsey [4] regarded the incorporation of one or more of the posterior pedigerous somites into the trunk as a key character in defining Peniculus, it was not mentioned in Castro-Romero's [7] diagnosis. After comparisons among related congeners (cf. Fig. 3), this relatively stable feature should be added to the generic diagnosis: pediger 4 or pedigers 3 and 4 incorporated into trunk.

The presence or absence of rami of legs is not mentioned in previous definitions of the genus, basically because the rami of the legs are typically missing in mature adult females. However, our observations of the new species described below have revealed remnants or scars of rami on the basis of the legs. This indicates that legs 1 and 2 are biramous, while legs 3 and 4 are uniramous. This configuration of the legs resembles that of other pennellid genera such as Sarcotretes and Lernaeenicus that retain the rami on the legs in the adult female (see Table 1 in [20]).

Peniculus hokutoae n. sp. [Japanese name: hokuto-kozutsu-hijikimushi (new)] (Figs. 1 and 2)

urn:Isid:zoobank.org:act:F0234087-38B2-4B36-9649F7CBE10B1FFC

Type. Holotype: ovigerous adult female attached to caudal fin of Symbolophorus evermanni (NSMT-P 132778), total length $50.9 \mathrm{~mm}$, collected at depths of 0-917.9 $\mathrm{m}$ in Suruga Bay $\left(35^{\circ} 03^{\prime} 20^{\prime \prime} \mathrm{N}, 138^{\circ} 41^{\prime} 00^{\prime \prime} \mathrm{E}\right)$, July 12, 2018; dissected, cephalothorax, mouthpart appendages and legs 1 and 2 in one slide, trunk and eggs in a vial (NSMT-Cr 25880). Japan.

Type-locality: Suruga Bay $\left(35^{\circ} 03^{\prime} 20^{\prime \prime} \mathrm{N}, 138^{\circ} 41^{\prime} 00^{\prime \prime} \mathrm{E}\right)$,

Description. Description. Ovigerous adult female. Body (Figs. 1A and 2A) comprising cephalothorax, comprising cephalosome covered with dorsal shield fused to secondarily elongate pediger 1 , small pediger 2 and cylindrical trunk in which pedigers 3 and 4 completely incorporated. Total length from anterior tip of cephalosome to posterior end of trunk $7.95 \mathrm{~mm}$. Cephalosome (Figs. 1C and 2A-2C) anteriorly produced into conical tip. Dorsal cephalic shield (Fig. 2B) trapezoidal, with anterior margin divided into three parts clearly visible in dorsal view. Middle part representing rostrum (Fig. 2B) truncate at tip, ornamented with two pairs of hairsensilla. Proboscis moderately produced ventrally, carrying oral cone at tip. Buccal cone without observed slits or scales. Pediger 1 fused to cephalosome (Figs. 1A and 2A-2C) secondarily elongated, $c a$. 1.6 times as long as dorsal cephalic shield, tapering posteriorly. Pediger 2 (Fig. 2A) small, wider than long. Trunk (Fig. 2A) about 4.6 times as long as a combination of cephalosome and pedigers 1 and 2. Trunk about 5.2 times as long as wide. Pediger 3 separate from pediger 4 . Tergites of pedigers 3 and 4 (Fig. 2A, arrowed) present. Abdomen vestigial. Paired gonopores located at posteriormost corner; two heavily chitinized ridges present medial to gonopore. Paired caudal rami (Fig. 2D) tiny, positioned close together subterminally; bearing six setae.

Antennule missing with paired scars visible (Fig. 2B). Antenna (Figs. 2E and 2F) heavily sclerotized, two-segmented, located on highly swollen, globular base; basal segment, expanded with two triangular processes; distal segment forming curved claw with sharply pointed tip, bearing minute setule basally. Mandible (Fig. 2G) slender, consisting of 3 parts: basal part globular; middle longest, cylindrical; distal recurved, with 10 teeth along inner margin of terminal expansion. Maxillule (Fig. 2H) unilobed with two unequal apical setae. Maxilla (Fig. 2I) two-segmented: basal segment robust, unarmed; distal segment with subterminal spinular row; terminal element small, ornamented with three rows of prominences.

Legs 1-4 all with partially divided protopod and intercoxal sclerite. Legs 1 (Fig. 2J) and 4 (Fig. 2M) each retaining remnant of rami. Legs 1 and 2 (Fig. 2K) biramous, while legs 3 (Fig. 2L) and 4 (Fig. 2M) uniramous, based on articulation scars on protopods. Left leg 4 (Fig. 2M) with two-segmented exopod, armed with outer seta on outer terminal corner of protopod; first segment unarmed, second segment with three setose setae, one weakly sclerotized seta and 1 minute spiniform seta. Right leg 4 lacking ramus.

Egg string linear (Figs. 1A and 1B): left egg string longer than body; right egg string incomplete.

Coloration. The specimen was still alive on collection, although the host was dead. The body coloration is based on this live specimen. The cephalothorax was translucent except for the naupliar eye (Figs. 1C and 1D). The trunk was entirely tinged with reddish brown with numerous pigmented droplets 


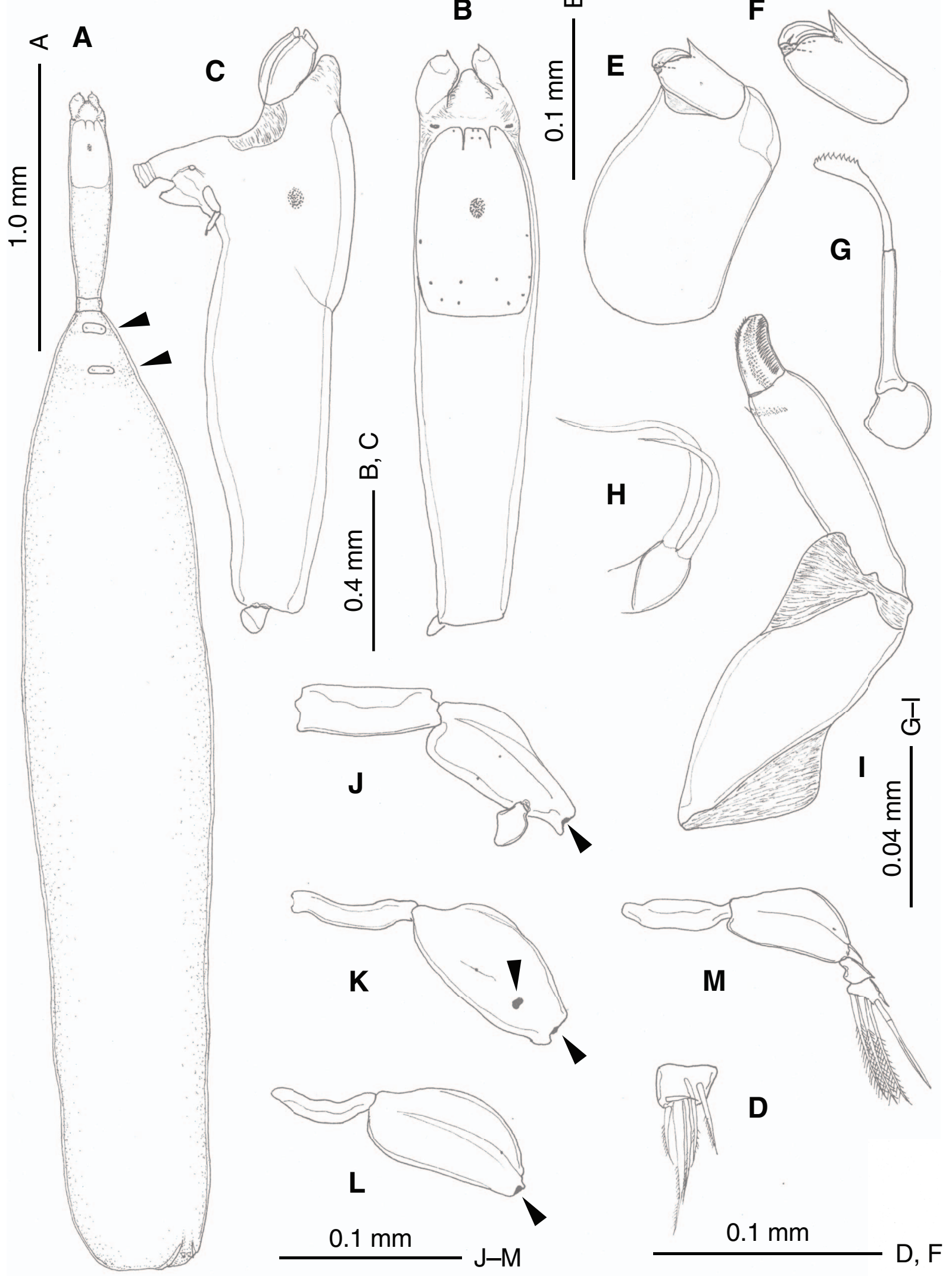

Figure 2. Peniculus hokutoae n. sp., holotype female. (A) Habitus, dorsal view, posterior part twisted, tergites on third and fourth pedigerous somites arrowed; (B) Cephalothorax, dorsal view; (C) Cephalothorax, lateral view; (D) Caudal ramus; (E) Antenna; (F) Terminal segment of antenna; (G) Mandible; (H) Maxillule; (I) Maxilla; (J) Leg 1, anterior view; (K) Leg 2, anterodistal view; (L) Leg 3, anterior view; (M) Leg 4, anterior view. Arrows in $(\mathrm{J})$ to $(\mathrm{L})$ indicate bases of rami. 

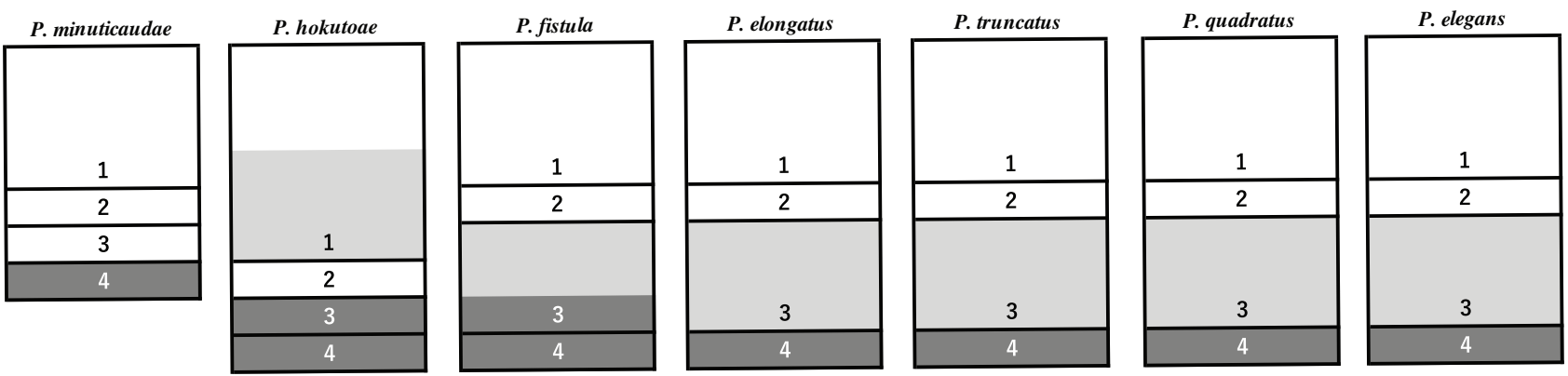

Figure 3. Schematic illustration of cephalothorax and pedigerous somites 1-4 of seven species of Peniculus. Numbers indicate relative positions of legs on pedigerous somites $1-4$. Light gray: elongated part; dark gray: trunk.

dorsally (Fig. 1B). Paired ovaries were yellowish in color (Fig. 1B). Eggs were light orange in color (Figs. 1A and 1B).

Remarks. The taxonomy of the genus Peniculus and related genera (Metapeniculus, Propeniculus Castro-Romero, 2014, Pseudopeniculus Castro-Romero, 2014) was revised by Castro-Romero [7] and Castro-Romero et al. [9]. The morphological features of the new species essentially fall within the diagnosis of Peniculus as redefined by Castro-Romero [7], although the structures of the maxillule, maxilla and legs differ slightly from those of other congeners.

The present new species is easily distinguished from other congeners by: (1) the secondary elongation of the first pedigerous somite (Fig. 3); (2) the third and fourth pedigerous somites are included in the trunk (Fig. 3); (3) the frontal expansion anterior to the rostrum; (4) unilobed maxillule bearing two terminal setae of unequal lengths; (5) the lack of a process on the first segment of the maxilla.

In the type specimen of the new species, some rami of legs still remain and the possibility of accidental detachment of the other rami during handling and observation of the specimen for this description cannot be ruled out.

Etymology. The new species is named after the research vessel Hokuto, of Tokai University.

\section{Discussion}

\section{Taxonomy}

The taxonomy of the genus Peniculus is still confused, although Castro-Romero [7], Castro-Romero and Kuroki [8], and Castro-Romero et al. [9] have revised the generic diagnosis. They tentatively recognized nine species in the genus: P. calamus von Nordmann, 1864; P. clavatus (Müller, 1799); P. communis Leigh-Sharpe, 1934; P. elegans Leigh-Sharpe, 1934; P. elongatus Boxshall, 1986; P. fistula von Nordmann, 1832; P. minuticaudae Shiino, 1956; P. ostraciontis Yamaguti, 1939; and P. truncatus Shiino, 1956. However, Kabata and Wilkes [14] pointed out that P. calamus and P. fissipes Wilson, 1917 can be relegated to synonymy with the type species P. fistula. Castro-Romero [7] included P. calamus in the genus without any comment on the proposal of Kabata and Wilkes [14].

Castro-Romero [7] established the two new genera Propeniculus and Pseudopeniculus to accommodate two species formerly placed in Peniculus. These type species are
Peniculus trichiuri Gnanamuthu, 1951 (senior synonym of P. theraponi Gnanamuthu, 1951, P. sciaenae Gnanamuthu, 1951, P. scomberi Gnanamuthu, 1951, P. stromatei Gnanamuthu, 1951) and Peniculus asinus Kabata \& Wilkes, 1977, respectively. In the same year, Moon and Choi [17] independently described a new species of Peniculus, P. quadratus Moon \& Choi, 2014 from Korea, and mentioned that 15 species were accommodated in the genus, including species now belonging to Propeniculus and Pseudopeniculus. Currently [5], 10 species, i.e., Castro-Romero's [7] nine species and P. quadratus are listed as valid in the genus. However, the description of $P$. communis by Leigh-Sharpe [15] is inadequate by modern standards and the exact identity cannot now be confirmed. The absence of any sign of the buccal cone in $P$. communis indicates a possible similarity to Propeniculus, but in this species the protopods of legs 1-4 can be clearly seen in Leigh-Sharpe [15], while in Propeniculus no legs were observed. Peniculus clavatus was redescribed by Leigh-Sharpe and Perkins [16] and appears to differ rather remarkably from other congeners, in the presence of a special frontal organ and antennules (see Fig. 3 in [16]). After consideration of the position and shape of this "frontal organ", we infer that this structure is probably the grasping antennae which were misinterpreted. The morphology of the antennae and maxillules also differs greatly from that of other congeners. Given these problems, we believe that these two species should be treated as incertae sedis. As pointed out by many taxonomists, a systematic revision of Peniculus based on modern taxonomic techniques is needed.

Based on the seven well-described species, four morphological patterns of the cephalothorax, neck and anterior parts of the trunk can be found (Fig. 3). In P. minuticaudae, the cephalothorax and neck are not elongate, and only the fourth pedigerous somite is incorporated into the trunk. In P. hokutoae n. sp., the part of the cephalothorax representing the first pedigerous somite is secondarily elongated, and both the third and fourth pedigerous somites are involved in the trunk. In the other five species, elongation of the third pedigerous somite is found. In P. fistula, the third and fourth pedigerous somites are both incorporated into the trunk, while in the other four species, only the fourth is involved.

\section{Host and distribution}

The known hosts and geographical distributions of Peniculus species are summarized in Table 1. Surprisingly, 
Table 1. Host, attachment site and distribution of Peniculus. -: no data.

\begin{tabular}{|c|c|c|c|}
\hline Species & Host (attachment site) & Distribution & Reference \\
\hline P. calamus von Nordmann, 1864 & unknown & Hawaii & {$[25]$} \\
\hline \multirow[t]{2}{*}{ P. clavatus (Müller, 1799) } & Sebastes norvegicus (Ascanius) (fin) & Iceland & [16] \\
\hline & S. norvegicus (fin), S. mentella Travin (fin) & Eastern North Atlantic & [28] \\
\hline P. communis Leigh-Sharpe, 1934 & $\begin{array}{l}\text { Atherina forskali Rupp (fin), Atherina pinguis } \\
\text { Lac (tail) }\end{array}$ & Ambon & {$[15]$} \\
\hline P. elegans Leigh-Sharpe, 1934 & Chromis caerulea (Cuvier) (as C. lepidurus) (-) & Anchorage Salomakie Is. & [15] \\
\hline P. elongatus Boxshall, 1986 & Pempheris affinis McCulloch (-) & New South Wales, Australia & [1] \\
\hline \multirow[t]{10}{*}{ P. fistula von Nordmann, $1832 *$} & $\begin{array}{l}\text { Chromis notata (Temminck \& Schlegel) (fin, } \\
\text { body surface) }\end{array}$ & Chuja Island, Korea & {$[17]$} \\
\hline & Anisotremus scapularis Tschudi (fin) & South Pacific coast of Chile & {$[9]^{* *}$} \\
\hline & Cheilotrema fasciatum Tschudi (fin) & & \\
\hline & Chromis crusma Valenciennes (fin) & & \\
\hline & Girella laevifrons Tschudi (fin) & & \\
\hline & Hemilutjanus macrophthalmus Tschudi (fin) & & \\
\hline & Isacia conceptionis Cuvier (fin) & & \\
\hline & Mugil cephalus Linnaeus (fin) & & \\
\hline & Odontesthes regia Humboldt (fin) & & \\
\hline & Prolatilus jugularis Valenciennes (fin) & & \\
\hline P. hokutoae n. sp. & Symbolophorus evermanni (Gilbert) (fin) & Suruga Bay, Japan & Present study \\
\hline \multirow[t]{8}{*}{ P. minuticaudae Shiino, 1956} & $\begin{array}{l}\text { Stephanolepis cirrhifer (Temminck \& Schlegel) } \\
\text { (fin) }\end{array}$ & Shirahama, Wakayama, Japan & {$[23]$} \\
\hline & Stephanolepis cirrhifer (fin) & Oita, Japan & [19] \\
\hline & Thamnaconus modestus (Gunther) (fin) & Oita, Japan & [19] \\
\hline & Thamnaconus modestus (fin) & Tongyeong, Korea & [24] \\
\hline & Aluterus monoceros (Linnaeus) (fin) & Aquarium in Kagoshima, Japan & [21] \\
\hline & Paramonacanthus japonicus (Tileslus) (fin) & Uwajima, Ehime, Japan & {$[13]$} \\
\hline & Roa modesta (Temminck \& Schlegel) (fin) & & \\
\hline & Stephanolepis cirrhifer (fin) & & \\
\hline \multirow[t]{2}{*}{ P. ostraciontis Yamaguti, 1939} & Tetrosomus gibbous Linnaeus (head) & Pacific & [29] \\
\hline & Tetrosomus concatenatus (Bloch) (head) & Sagami Bay, Japan & [23] \\
\hline P. quadratus Moon \& Choi, 2014 & $\begin{array}{l}\text { Neoditrema ransonnetii Steindachner (mouth } \\
\text { palate) }\end{array}$ & Chuja Island, Korea & {$[17]$} \\
\hline \multirow[t]{3}{*}{ P. truncatus Shiino, 1956} & Sebastes oblongus (Gunther) (fin) & Off Wagu, Mie, Japan & {$[23]$} \\
\hline & Sebastes schlegelii Hilgendorf (fin) & Kamak Bay, Korea & {$[10]$} \\
\hline & Sebastes schlegelii (fin) & Tongyeong, Korea & [24] \\
\hline
\end{tabular}

* As for P. fistula, hosts are listed on the basis of two references published after Bunkley-Williams \& William [6] in which two superorders, six orders, 19 families and 33 species of host fish were recorded worldwide.

${ }_{* *}$ Castro-Romero et al. [9] identified the taxon examined as Peniculus cf. fistula.

P. fistula (including $P$. cf. fistula sensu Castro-Romero et al. [9]) infests a wide range of hosts (two superorders, six orders, 20 families, 42 species) occurring across the world. Castro-Romero et al. [9] reported low genetic diversity of the populations of $P$. cf. fistula parasitic on nine species of hosts occurring off the coast of Chile, irrespective of some intraspecific morphological variation. In contrast, other species exhibit relatively limited host-specificity in a restricted geographical area. For example, the hosts of $P$. minuticaudae and $P$. truncatus seem to be restricted to East Asian fish belonging to the Monacanthidae and Sebastidae, respectively. One exceptional case in P. minuticaudae was parasitism on brown-banded butterflyfish Rao modesta, but this seems to have occurred in the artificial conditions of an aquarium tank [21].

It is most likely that the host-usage of Peniculus species other than P. hokutoae n. sp. is restricted to coastal or epipelagic fish. In contrast, the host of P. hokutoae n. sp. is a mesopelagic myctophid Symbolophorus evermanni [18].
This is the first record of the occurrence of any Peniculus on a member of the family Myctophidae. This host family is frequently utilized by deep-sea pennellids including species of Sarcotretes, Lernaeenicus and Cardiodectes [20], but never before by a Peniculus. This parasitism could be explained by the following evolutionary scenario. Myctophids are mainly distributed in meso- and bathypelagic zones, and many species exhibit diel vertical migration [18, 26, 27]. Symbolophorus evermanni is one of the dominant myctophid fish that occur nocturnally in surface waters of the Kuroshio region in the northwestern Pacific (Watanabe and Kawaguchi [26]). The myctophid is distributed at depths of $600-1150 \mathrm{~m}$ during daytime and upper $125 \mathrm{~m}$ at night [18, 26, 27] and can be ecologically classified as a migrant [27]. Exposure to infective stages of the Peniculus could have occurred nocturnally while the hosts were in the surface waters. Once on the new host, the copepod would eventually have adapted to its deep-sea myctophid host. 
Acknowledgements. We would like to express our sincere thanks to the captain Mr. Iwao Hashigaya and the chief engineer, Mr. Hidetsugu Sakata of R/V Hokuto, Tokai University for their cooperation at sea, and to Drs. Hironori Komatsu and Gento Shinohara for our deposition of the biological specimens in the National Museum of Nature and Science, Tsukuba, Japan. This study was carried out as a part of the SURUME (SUruga bay Research for Understanding Marine Ecosystems) project, and we thank all scientists and students on-board. This study was partially supported by grants-in-aid KAKEN from the Japan Society of the Promotion of Science (Nos. 16K07825 and 26304030). The authors declare that they have no conflicts of interest.

\section{References}

1. Boxshall GA. 1986. A new genus and two new species of Pennellidae (Copepoda: Siphonostomatoida) and an analysis of evolution within the family. Systematic Parasitology, 8, 215-225.

2. Boxshall GA. 1989. Parasitic copepods of fishes: a new genus of the Hatschekiidae from New Caledonia, and new records of the Pennellidae, Sphyriidae and Lernanthropidae from the South Atlantic and South Pacific. Systematic Parasitology, 13, 201-222.

3. Boxshall GA. 1998. Host specificity in copepod parasites of deep-sea fishes. Journal of Marine Systems, 15, 215-223.

4. Boxshall GA, Halsey SH. 2004. Introduction to Copepod Diversity. The Ray Society: London.

5. Boxshall GA, Walter TC. 2012. Pennellidae Burmeister, 1835. In: Walter TC, Boxshall GA. 2017. World of Copepods database. Accessed through: World Register of Marine Species at http://www.marinespecies.org/aphia.php? $\mathrm{p}=$ taxdetails\&id= 135532 on 2018-08-28.

6. Bunkley-Williams L, Williams EH Jr. 2009. Hosts and distribution of Peniculus fistula Von Nordman, 1832. Reviews in Fisheries Science, 17, 538-540.

7. Castro-Romero R. 2014. Two new genera of pennellids (Copepoda, Siphonostomatoida): Propeniculus and Pseudopeniculus, each with a new combination, Propeniculus trichiuri (Gnanamuthu, 1951) and Pseudopeniculus asinus (Kabata \& Wilkes, 1977). Crustaceana, 87, 551-569.

8. Castro-Romero R, Kuroki HB. 1985. Metapeniculus antofagastensis gen. et sp. nov. (Copepoda, Pennellidae) parasitic on two inshore fishes of Antofagasta, Chile, South Pacific. Crustaceana, 49, 22-29.

9. Castro-Romero R, Montes MM, Martorelli SR, Sepulveda D, Tapia S, Martinez-Aquino A. 2016. Integrative taxonomy of Peniculus, Metapeniculus, and Trifur (Siphonostomatoida: Pennellidae), copepod parasites of marine fishes from Chile: species delimitation analyses using DNA barcoding and morphological evidence. Systematics and Biodiversity, 14, 466-483.

10. Choi S-D, Suh H-L, Hong S-Y. 1996. Two species of parasitic copepods (Neobrachiella incurva and Peniculus ostraciontis) from the marine fishes, Halichoeres poecilopterus and Sebastes schlegeli, of the south coast of Korea. Journal of Aquaculture, $9,117-123$.

11. Humes AG, Gooding RU. 1964. A method for studying the external anatomy of copepods. Crustaceana, 6, 238-240.

12. Huys R, Boxshall GA. 1991. Copepod evolution. The Ray Society: London.
13. Ismail N, Ohtsuka S, Venmathi Maran BA, Tasumi S, Zaleha K, Yamashita H. 2013. Complete life cycle of a pennellid Peniculus minuticaudae Shiino, 1956 (Copepoda: Siphonostomatoida) infecting cultured threadsail filefish, Stephanolepis cirrhifer. Parasite, 20, 42.

14. Kabata Z, Wilkes SN. 1977. Peniculus asinus (Copepoda: Pennellidae), a new species of copepod parasitic on fishes of the genus Sebastes along the west coast of North America. Canadian Journal of Zoology, 55, 1988-1991.

15. Leigh-Sharpe WH. 1934. The Copepoda of the Siboga Expedion. II. Commensal and parasitic Copepoda. Siboga Expedition Monograph, 29b, 1-43.

16. Leigh-Sharpe WH, Perkins MG. 1924. Some parasitic Copepoda from Iceland. With an account of Peniculus clavatus, the conjunctive tubes of Chondracanthus nodosus and the males of Clavella dubia. Parasitology, 16, 289-295.

17. Moon SY, Choi SH. 2014. Description of two species of Peniculus von Nordmann, 1832 (Copepoda: Siphonostomatoida: Pennellidae) parasitic on commercial fishes from Korea, including a new species. Systematic Parasitology, 88, 185-193.

18. Nakabo T. 2013. Fishes of Japan with pictorial keys to the species, 3rd edn. Tokai University Press: Hadano (In Japanese).

19. Nagasawa K, Fukuda Y, Tanaka S. 2011. Infection with Peniculus minuticaudae (Copepoda: Pennellidae) on threadsail filefish (Stephanolepis cirrhifer) and black scraper (Thamnaconus modestus) farmed in Japan. Biosphere Science, 50, 43-47.

20. Ohtsuka S, Lindsay DJ, Izawa K. 2018. A new genus and species of the family Pennellidae (Copepoda, Siphonostomatoida) infecting the Pacific viperfish Chauliodus macouni. Parasite, 25, 6.

21. Okawachi H, Uyeno D, Ogino K, Nagasawa K. 2012. Redescription of Peniculus minuticaudae Shiino, 1956 (Copepoda: Pennellidae) from aquarium-held marine fishes in Japan, with notes on its occurrence and life cycle in captivity. Zoosymposia, 8, 56-68.

22. Omori M. 1965. A 160-cm opening-closing plankton net. I. Description of the gear. Journal of the Oceanographical Society of Japan, 21, 212-220.

23. Shiino SM. 1958. Copepods parasitic on Japanese fishes. 17. Lernaeidae. Report of the Faculty of Fisheries, Prefectural University of Mie, 3, 75-100.

24. Venmathi Maran B, Moon SY, Oh SY, Soh HY, Myoung JG. 2012. Redescription of two pennellids (Copepoda, Siphonostomatoida) from Korea with a key to species of Peniculus von Nordmann, 1832. ZooKeys, 243, 1-14.

25. von Nordmann A. 1864. Neue Beitrage zur Kenntniss Parasitischer Copepoden. Bulletin de la Société Impériale des Naturalistes de Moscou, 27, 461-520.

26. Watanabe H, Kawaguchi K. 2003. Decadal change in abundance of surface migratory myctophid fishes in the Kuroshio region from 1957 to 1994. Fisheries Oceanography, 12, 100-111.

27. Watanabe H, Moku M, Kawaguchi K, Ishimaru K, Ohno A. 1999. Diel vertical migration of myctophid fishes (Family Myctophidae) in the transitional waters of the western North Pacific. Fisheries Oceanography, 8, 115-127.

28. Williams IC. 1963. The infestation of the redfish Sebastes marinus (L.) and $S$. mentella Travin (Scleroparei: Scorpaenidae) by the copepods Peniculus clavatus (Müller), Sphyrion lumpi (Krøyer) and Chondracanthopsis nodosus (Müller) in the eastern North Atlantic. Parasitology, 53, 501-525.

29. Yamaguti S. 1939. Parasitic copepods from fishes of Japan. Part 6. Lerneopodoida, I. Volumen. Jubilare pro Professore Sadao Yoshida, 2, 531-572. 
Cite this article as: Ohtsuka S, Nishikawa J \& Boxshall GA. 2018. A new species of Peniculus (Copepoda: Siphonostomatoida) parasitizing mesopelagic myctophid fish: first discovery of colonization of the genus in deep water. Parasite 25, 58.

\section{- PARASTE}

An international open-access, peer-reviewed, online journal publishing high quality papers on all aspects of human and animal parasitology

Reviews, articles and short notes may be submitted. Fields include, but are not limited to: general, medical and veterinary parasitology; morphology, including ultrastructure; parasite systematics, including entomology, acarology, helminthology and protistology, and molecular analyses; molecular biology and biochemistry; immunology of parasitic diseases; host-parasite relationships; ecology and life history of parasites; epidemiology; therapeutics; new diagnostic tools.

All papers in Parasite are published in English. Manuscripts should have a broad interest and must not have been published or submitted elsewhere. No limit is imposed on the length of manuscripts.

Parasite (open-access) continues Parasite (print and online editions, 1994-2012) and Annales de Parasitologie Humaine et Comparée (1923-1993) and is the official journal of the Société Française de Parasitologie. 